\title{
Uji Daya Hambat Virgin Coconut Oil Plus terhadap Pertumbuhan Bakteri Streptococcus mutans
}

\author{
Ewithya H. Hassan \\ Kustina Zuliari \\ Christy N. Mintjelungan \\ Program Studi Pendidikan Dokter Gigi Fakultas Kedokteran
Universitas Sam Ratulangi Manado
Email: hadisiswanto0503@gmail.com
}

\begin{abstract}
Dental caries is caused by a variety of factors, and the most important one is bacteria Streptococcus mutans. This disease could be prevented inter alia by using mouthwash. Albeit, mouthwash contains synthetic chemical ingredients which might be harmful to our health. Virgin coconut oil plus (VCO plus) can be used as a herbal medicine to inhibit the growth of bacteria in the oral cavity. This study was aimed to test whether the VCO plus had an inhibitory effect on the growth of Streptococcus mutans. This was an experimental laboratory study, using pure experimental design (true experimental design) with the post test only control design. We used modified Kirby-Bauer method with filter paper. Pure VCO plus obtained from the laboratory at Faculty of Mathematics and Natural Science University of Sam Ratulangi Manado was tested for its inhibitory effect. Erythromycin was used as the positive control and aquadest as the negative control. The results showed that the mean inhibitory zone of VCO plus to Streptococcus mutans was $10.22 \mathrm{~mm}$ which was categorized as moderate according to Davis and Stout. The mean inhibitory zone of VCO plus was less than of erythromycin. Conclusion: Virgin coconut oil plus had moderate inhibitory effect to Streptococcus mutans.
\end{abstract}

Keywords: dental caries, virgin coconut oil plus, Streptococcus mutans

\begin{abstract}
Abstrak: Karies gigi disebabkan oleh berbagai faktor, namun yang paling berperan yaitu Streptococcus mutans. Salah satu cara untuk mencegah karies gigi, antara lain menggunakan obat kumur. Namun obat kumur yang digunakan saat ini banyak mengandung bahan sintetis yang berefek kurang baik. Bahan alam yang banyak digunakan untuk menghambat pertumbuhan bakteri yaitu virgin coconut oil plus (VCO plus). Penelitian ini bertujuan untuk menguji daya hambat VCO plus terhadap pertumbuhan Streptococcus mutans. Jenis penelitian ialah eksperimental laboratorium, menggunakan rancangan eksperimental murni (true experimental design) dengan post test only control design. Metode yang digunakan ialah modifikasi KirbyBauer menggunakan kertas saring. Bahan uji ialah VCO plus yang diperoleh dari laboratorium F-MIPA Univeristas Sam Ratulangi, dengan kontrol positif eritromisin dan kontrol negatif akuades. Hasil penelitian mendapatkan rerata diameter zona hambat VCO plus terhadap Streptococcus mutans sebesar $10,22 \mathrm{~mm}$ yang termasuk kategori sedang berdasarkan penggolongan Davis dan Stout. Diameter zona hambat VCO plus lebih kecil dibandingkan dengan diameter zona hambat dari antibiotik (eritromisin). Simpulan: Virgin coconut oil plus mempunyai daya hambat kategori sedang terhadap pertumbuhan Streptococcus mutans.
\end{abstract}

Kata kunci: karies gigi, virgin coconut oil plus, Streptococcus mutans

Rongga mulut merupakan tempat kumpulan bakteri yang paling banyak dalam organ tubuh, salah satunya yaitu bakteri penyebab karies gigi. Karies gigi merupakan penyakit gigi dan mulut yang terjadi pada jaringan keras gigi (email, dentin, dan sementum) 
dan memiliki angka prevalensi cukup tinggi di masyarakat Indonesia. Berdasarkan Riset Kesehatan Dasar (Riskesdas) Nasional tahun 2013, prevalensi nasional masalah kesehatan gigi dan mulut mencapai $25,9 \%$. Sebanyak 14 provinsi di Indonesia memiliki prevalensi masalah kesehatan gigi dan mulut melebihi prevalensi nasional. Di Sulawesi Utara sebanyak $31,6 \%$ penduduk memiliki masalah kesehatan gigi dan mulut. $^{1}$

Terdapat bermacam-macam penyebab terjadinya karies gigi, yaitu antara lain: host (penjamu), waktu, substrat, dan mikroorganisme, namun yang paling utama berperan untuk terjadinya karies gigi yaitu Streptococcus mutans. Bakteri ini merupakan flora normal dalam rongga mulut, tetapi bisa menjadi faktor penyebab terjadinya kerusakan gigi atau karies. Sisa-sisa makanan akan diuraikan oleh bakteri menjadi asam kemudian asam yang terbentuk akan menempel pada email sehingga terjadi demineralisasi. Bila proses demineralisasi tersebut berlangsung terus menerus dalam rongga mulut maka akan berakibat terjadinya karies gigi. ${ }^{2,3}$

Karies gigi dapat dicegah yaitu dengan menyikat gigi secara tepat dan benar, serta menggunakan benang gigi dan obat kumur. Namun obat kumur yang digunakan saat ini banyak mengandung bahan sintetis yang mempunyai efek kurang baik dalam kesehatan bila sering digunakan setiap hari. Penggunaan bahan alami mulai dikembangkan baik dalam bidang kedokteran maupun kedokteran gigi. Salah satu bahan alami yang banyak digunakan untuk menghambat pertumbuhan bakteri yaitu VCO plus.

Virgin coconut oil plus (VCO plus) merupakan produk khas daerah Sulawesi Utara dan berkhasiat untuk kesehatan, di antaranya menurunkan risiko kanker, membantu mencegah infeksi virus, mendukung sistem kekebalan tubuh, dan membantu kulit tetap halus. Penelitian yang dilakukan oleh Pulung et $\mathrm{al}^{4}$ di Manado pada tahun 2016, melaporkan bahwa terdapat daya hambat VCO plus terhadap pertumbuhan bakteri Staphylococcus aureus, tetapi penelitian terhadap bakteri lain belum dilakukan.
Penelitian ini bertujuan untuk mendapatkan daya hambat VCO plusterhadap pertumbuhan bakteri Streptococcus mutans.

\section{METODE PENELITIAN}

Metode pengujian yang digunakan yaitu metode modifikasi Kirby-Bauer dengan menggunakan paper disc. Bakteri Streptococcus mutans yang disimpan di media agar diambil dari stok bakteri murni yang dibiakkan langsung di Laboratorium Fakultas Matematika dan Ilmu Pengetahuan Alam (F-MIPA) Universitas Sam Ratulangi. Bakteri diambil dengan jarum ose lalu ditanamkan pada media agar miring dengan cara menggores. Bakteri yang telah digores pada media agar diinkubasi dalam inkubator pada suhu $37^{0} \mathrm{C}$ selama 1 x 24 jam. Bakteri yang telah diinkubasi diambil koloninya dari media agar miring dengan menggunakan jarum ose steril kemudian dimasukkan ke dalam media BHI-B sampai kekeruhannya sama dengan standar McFarland. Lidi kapas steril dicelupkan ke dalam suspensi bakteri hingga basah. Lidi kapas diperas dengan menekankan pada dinding tabung reaksi bagian dalam, kemudian digores merata pada media NA sampai permukaannya tertutupi. Setelah itu diletakkan disk eritromisin, kertas saring pertama dicelupkan ke dalam aquades dan kertas saring kedua dicelupkan dalam larutan VCO plus. Selanjutnya cawan Petri diinkubasi dalam inkubator dengan suhu $37^{\circ} \mathrm{C}$ selama $1 \times 24$ jam dengan lima kali pengulangan.

\section{HASIL PENELITIAN}

Pada penelitian ini zona hambat yang terbentuk pada lima cawan Petri yang telah diberi perlakuan dan telah diinkubasi selama $1 \times 24$ jam pada suhu $37^{\circ} \mathrm{C}$ diukur menggunakan penggaris dalam satuan milimeter dan dimasukan dalam tabel pengamatan. Tabel 1 memperlihatkan bahwa diameter zona hambat yang terbentuk berbeda pada tiap cawan Petri. Hasil pengukuran diameter zona hambat yang terbentuk pada cawan Petri yang berisi kertas saring VCO plus memiliki rerata $10,22 \mathrm{~mm}$ sedangkan pada cawan Petri yang berisi kertas saring eritromisin memiliki rerata $37,56 \mathrm{~mm}$. 
Tabel 1. Hasil pengukuran diameter zona hambat bakteri Streptococcus mutans

\begin{tabular}{cccc}
\hline \multicolumn{4}{c}{ Diameter zona hambat $(\mathbf{m m})$} \\
\hline Pengulangan & $\begin{array}{c}\text { Virgin coconut oil } \\
\text { Plus }\end{array}$ & $\begin{array}{c}\text { Kontrol positif } \\
\text { (eritromisin) }\end{array}$ & $\begin{array}{c}\text { Kontrol negatif } \\
\text { (aquades) }\end{array}$ \\
\hline I & 9,6 & 39,5 & 0 \\
II & 10 & 30,7 & 0 \\
III & 10,5 & 39,35 & 0 \\
IV & 10,5 & 38,45 & 0 \\
V & 10,5 & 39,8 & 0 \\
Rerata & 10,22 & 37,56 & 0 \\
\hline
\end{tabular}

\section{BAHASAN}

Hasil pengamatan yang dilakukan pada sampel yang diberikan perlakuan dengan lima kali pengulangan, menunjukkan bahwa virgin coconut oil plus memiliki efek anti bakteri terhadap Streptococcus mutans. Pada penelitian ini terdapat perbedaan maupun persamaan dari setiap hasil pengulangan baik pada diameter zona hambat VCO plus maupun pada kontrol positif (eritromisin) yaitu pada pengulangan pertama memiliki diameter zona hambat VCO plus sebesar 9,6 mm yang lebih kecil jika dibandingkan diameter pada pengulangan ketiga, keempat, dan kelima yang mempunyai diameter sama besar yaitu 10,5 $\mathrm{mm}$.

Pada pengulangan pertama diameter kontrol positif (eritromisin) memiliki diameter zona hambat sebesar 39,5 mm. Hasil ini lebih besar jika dibandingkan pada pengulangan kedua yang mempunyai diameter zona hambat sebesar $30,7 \mathrm{~mm}$. Hal ini mungkin disebabkan karena kertas saring yang digunakan memiliki kekurangan yaitu tidak bisa mengontrol banyaknya sediaan yang terserap pada masing-masing kertas saring, sehingga membuat hasil diameter zona hambat berbeda-beda walaupun diambil dari suspensi yang sama.

Zona hambat yang terbentuk di sekitar cakram kertas saring yang diberi VCO plus menunjukkan bahwa kandungan senyawa metabolit sekunder yang terkandung di dalamnya seperti asam laurat memiliki efek antibakteri. ${ }^{4}$ Asam laurat atau asam dodekanoat memiliki rumus molekul $\mathrm{C}_{12} \mathrm{H}_{24} \mathrm{O}_{2}$. Asam laurat berbentuk kristal padat, berwarna putih, memiliki titik didih $298,9^{\circ} \mathrm{C}$ (pada $760 \mathrm{~mm} \mathrm{Hg}$ ) dan titik cair 44,0 $44,2^{\circ} \mathrm{C}$. Minyak nabati tropis sumber asam laurat yaitu minyak kelapa dan minyak intisawit. Asam laurat dalam tubuh akan diubah menjadi monolaurin yang bersifat anti bakteri. ${ }^{5}$

Bakteri Gram positif memiliki kandungan lipid yang rendah yaitu sebesar 14\% bila dibandingkan dengan bakteri Gram negatif yang mempunyai kandungan lipid sebesar $11-22 \%$. Bakteri Gram positif hanya memiliki satu lapis membran peptidoglikan yang tebal. ${ }^{6}$ Hal tersebut dapat menyebabkan pertumbuhan bakteri Streptococcus mutans dapat dihambat oleh virgin coconut oil plus yang mengandung zat antibakteri.

Hasil penelitian ini juga menunjukan bahwa rerata diameter zona hambat yang terbentuk pada kontrol positif (eritromisin) lebih besar $(37,56 \mathrm{~mm})$ dibandingkan dengan rerata diameter zona hambat virgin coconut oil plus $(10,2 \mathrm{~mm})$. Perbedaan ini menunjukkan bahwa efek anti bakteri yang dimiliki oleh eritromisin terhadap bakteri Streptococcus mutans lebih kuat dibandingkan dengan VCO plus. Kadar hambat minimum dari kontrol positif (eritromisin) telah diketahui, sehingga memengaruhi terbentuknya diameter zona hambat yang lebih besar. Selain itu, konsentrasi dari jenis senyawa aktif yang bertanggung jawab memberikan efek anti bakteri dari VCO plus belum diketahui, sehingga rerata zona hambat yang terbentuk lebih kecil dibandingkan dengan rerata zona hambat yang terbentuk pada antibiotik eritromisin sebagai kontrol positif.

Limitasi penelitian ini yaitu pada saat 
meratakan jumlah koloni bakteri Streptoccocus mutans yang menyebar di media Muller-Hinton Agar (MHA) tidak tersebar merata di tiap bagian cawan Petri, sehingga membuat hasil berbeda-beda.

\section{SIMPULAN}

Berdasarkan hasil penelitian ini dapat disimpulkan bahwa virgin coconut oil plus memilik daya hambat yang dikategorikan sebagai daya hambat sedang terhadap pertumbuhan bakteri Streptococcus mutans

\section{SARAN}

Diharapkan dapat dilakukan penelitian lebih lanjut mengenai efek anti bakteri minyak virgin coconut oil plus pada suspensi bakteri Staphylococcus aureus dengan menggunakan metode sumuran.

Perlu dilakukan penelitian lebih lanjut mengenai efektivitas virgin coconut oil plus terhadap bakteri Streptococcus mutans pada berbagai konsentrasi, sehingga dapat diketahui Minimal Inhibitory Concentration dari virgin coconut oil plus terhadap bakteri tersebut.

\section{DAFTAR PUSTAKA}

1. Badan Penelitian dan Pengembangan Kesehatan. Riset kesehatan dasar Riskesdas 2013. Jakarta: Kementerian Kesehatan RI, 2013; p. 147-54.

2. Imaculata R, Tedjosasongko U, Cornelia S. Pemberian minyak wijen (Sesamumindicum, L) terhadap Streptococcus mutans (in vitro). Indonesian Pediatric Dental Journal. 2010;2(3):2.

3. Tarigan R. Karies Gigi (2nd ed). Jakarta: EGC, 2013; p. 1,75-7.

4. Pulung ML, Yogaswara R, Fajar RDN, Sianipar FRDN. Potensi antioksidan dan antibakteri virgin coconut oil dari tanaman kelapa asal Papua. Chem Prog. 2016;9(2):75-82.

5. Bhatnagar AS, Kumar $P$, Hemavathy $J$, Gopala K. Fatty acid composition, oxidative stability and radical scavenging activity of vegetable oil blends with coconut oil. J Am Oil Chem Soc. 2009;86(10):991-9.

6. Wijaya D. Daya hambat teh hitam, teh hijau, dan teh oolong terhadap pertumbuhan Streptococcus mutans. 2012. [cited 2016 Feb 21]. Available from: http//www.pdgionline.com/v2/index.p hp?option. 